\title{
HRAS Gene Mutation Negative
}

National Cancer Institute

\section{Source}

National Cancer Institute. HRAS Gene Mutation Negative. NCI Thesaurus. Code C160373.

A genetic finding indicating that HRAS gene mutations have not been detected in a sample. 